\title{
A Meta-Analytical Review of Gender-Based School Bullying in Spain
}

\author{
Sandra Feijóo ${ }^{1}$ (D) and Raquel Rodríguez-Fernández ${ }^{2, *(\mathbb{D})}$ \\ 1 Department of Social Psychology, Basic Psychology, and Methodology, Universidade de Santiago de \\ Compostela (USC), 15782 Santiago de Compostela, Spain; sandra.sanmartin@usc.es \\ 2 Department of Methodology of Behavioral Sciences, Faculty of Psychology, Universidad Nacional de \\ Educación a Distancia (UNED), 28040 Madrid, Spain \\ * Correspondence: rrodriguez@psi.uned.es
}

Citation: Feijóo, S.;

Rodríguez-Fernández, R. A

Meta-Analytical Review of

Gender-Based School Bullying in

Spain. Int. J. Environ. Res. Public Health 2021, 18, 12687. https:// doi.org/10.3390/ijerph182312687

Academic Editors: Antonio Jesús Rodríguez-Hidalgo and Daniel Falla Fernández

Received: 26 September 2021

Accepted: 28 November 2021

Published: 1 December 2021

Publisher's Note: MDPI stays neutral with regard to jurisdictional claims in published maps and institutional affiliations.

Copyright: (c) 2021 by the authors. Licensee MDPI, Basel, Switzerland. This article is an open access article distributed under the terms and conditions of the Creative Commons Attribution (CC BY) license (https:/ / creativecommons.org/licenses/by/ $4.0 /)$.
Abstract: School bullying continues to be one of the main challenges for the education community. Current research indicates that Lesbian, Gay, Bisexual, Transgender, Transsexual, and other LGBT+ people suffer the highest rates of bullying, while other studies suggest that this bullying does not occur based on the victim's actual sexual orientation or gender identity, but because they do not fit into the traditional gender roles. The aim of the present study was to carry out a meta-analytical study on the prevalence of gender-based bullying against LGBT+ schoolchildren and adolescents in Spain. Methods: The review was carried out following the recommendations of the PRISMA group and allowing us to identify a total of 24 studies. All of these studies were published since 2008, and most of them conducted cross-sectional survey-type research. It was also found that the instrument used to assess bullying varied greatly among studies, resulting in an enormous heterogeneity of research on this topic. Different meta-analyses were carried out according to the profile of involvement in bullying: victimisation, perpetration, and observation. In addition, three target populations were detected in the victimisation research: the general population, pre-identified bullying victims reporting the reasons behind the victimisation, and LGBT+ people. Results: The meta-analyses conducted with $\mathrm{R}$ have estimated the prevalence of observation of gender-based school bullying in Spain at $77.3 \%$, perpetration at $13.3 \%$, and victimisation at $8.6 \%$ among the general population. When the research focuses on previously identified victims, the rate was $3.6 \%$, while if LGBT+ people are approached directly, the percentage increases to $51 \%$. Conclusions: These rates reveal the need to develop specific preventive strategies in schools. Greater awareness of affective-sexual diversity and respect for those who do not conform to traditional gender roles should be promoted.

Keywords: bullying; gender; LGBT-phobia; prevalence; meta-analysis

\section{Introduction}

Bullying has been defined as deliberate aggression or intentional harm-doing carried out by one or several people repeatedly and over time in an interpersonal setting characterised by an imbalance of power, either real or perceived [1]. Research has suggested that any person or group different in some way from "the majority" is particularly vulnerable to victimisation [2-5]. There is even research that refers to Lesbian, Gay, Bisexual, Transgender, Transsexual, and other LGBT+ people as those who suffer the highest rates of school bullying and harassment in general [6,7]. In this sense, a person can be repeatedly exposed to exclusion, isolation, threats, insults, and physical aggression by those who use homophobia, sexism, and other values associated with heterosexism as justification [8].

There is a conceptual debate about how to define bullying specifically among LGBT+ people [9]. One of the key aspects of why it is so difficult to name this issue is that this bullying does not occur due to the true sexual orientation or identity of the victims, but because they do not fit into the traditional gender roles in some way $[5,10]$. Moreover, some authors have suggested that it could be included in the framework of gender-based 
violence [9,11], although in the Spanish context, it is only legally recognised as such when a man mistreats a woman with whom he has or has had a sentimental relationship [12]. Examples of people who are not perceived or represented by normative gender patterns would be feminists, who have often been called "lesbians", or men who engage in activities considered "unsuitable" for their sex who are labelled as "fags", especially by other men and regardless of the orientation of their sexual desire $[8,13]$. In addition, parents of LGBT+ children may also experience homophobic bullying, just as there is a sort of "contagion" of the stigma towards friends of LBGT+ people or even those who defend victims of homophobia [8]. Although different bullying research has used names linked to homophobia such as lesbophobia, biphobia, transphobia, or LGBT-phobia $[9,14]$, the present research will use the term "gender-based bullying" in order to reflect the various theories that highlight the importance of traditional gender roles in this context $[5,8-11,13]$.

From a global perspective, the Rainbow Europe website currently ranks Spain in eighth place among 49 Eurasian countries in which LGBT+ rights have been achieved, with an estimated $65 \%$ in the scope of human rights for this group, explicitly mentioning Education as one of the areas showing the greatest progress, thanks to the Organic Law 8/2013 of 9 December for the improvement of educational quality [15]. However, with regard to the school setting, in particular, Generelo and Pichardo [14] published a report pointing out the lack of institutional and academic attention to LGBT+ violence, while other publications have generalised the problem to all institutions or even to the Spanish society as a whole, characterising it as sexist and homophobic [16,17]. In this sense, a report published in 2015 found that $88 \%$ of students in secondary education reported having witnessed, at least once, taunts and insults related to sexual orientation and/or gender identity, such as "faggot", "dyke", or "tomboy" [18]. As a counterpoint, another 2016 report noted that only $3.2 \%$ of victims of bullying and $4.2 \%$ of victims of cyber-bullying perceived that they had been bullied due to their sexual orientation [19].

To sum up, it can be stated that gender-based school bullying is a problem that is difficult to conceptualise, all of which is compounded by the presence of contradictory information regarding its prevalence in Spain. However, no study seems to have been carried out to synthesise the knowledge about this type of bullying in our country. Therefore, the main objective of the present study was to carry out a meta-analytical review of gender-based bullying at schools in the Spanish context.

\section{Materials and Methods}

The meta-analytical review was conducted on the basis of the recommendations provided by the PRISMA group [20], Botella and Gambara [21], and Botella and SánchezMeca [22] but was not registered in the PROSPERO database (International Prospective Register of Systematic Reviews).

Three dimensions were defined for the bibliographic search: the problem to be studied (bullying), the population under study (the LGBT+ community), and a spatial dimension (the Spanish context). The terms used in the search refer to each of these dimensions in both Spanish and English in an attempt to be as exhaustive as possible, given the aforementioned terminological difficulties. The terms of the same dimension have been used with the connector "OR" or equivalent depending on the database used, while the dimensions have been linked with "AND" or equivalent. Terms related to bullying were searched for in the keywords field, while those related to the population could be anywhere in the text in an attempt to cover research that had included LGBT+ people, although not as the main focus of the study. The terms for bullying were: Bully*, Cyberbull ${ }^{*}$, Harass*, Bulli*, Violen*, Aggress* and Perpetrat*; with the Spanish equivalents Acos*, Ciberacos*, Hostiga*, Ciberbull ${ }^{*}$, Bulli* and Agres*. For the LGBT+ community, the terms were: Homophob*, Gender, "sexual orientation", LGB*, Trans*, and Queer; with the Spanish equivalents Homofob*, Género, "orientación sexual", LGB*, Trans* and Queer.

The databases Scopus, Dialnet, and Eric ProQuest, were used for the review, as well as the meta-search engine EBSCO Host. This systematic review was conducted between 
August and September 2020. The use of numerous search terms, some of them of an ambiguous nature (such as Trans*), resulted in the return of a wide range of results in the databases. Of these results, 110 were identified as being of potential interest to the present study. The inclusion criterion was that the research addressed school bullying or harassment at non-university levels with reference to gender, sexual orientation, or identity, and the exclusion criterion was that the target population did not belong to the Spanish territory. No time criterion was used so that all studies found were included regardless of their year of publication. Furthermore, in order to try to detect as many publications as possible, a manual review of the journals, Journal of Homosexuality, Aggressive Behavior, and International Journal of Bullying Prevention, was conducted. The Researchgate profiles of José Ignacio Pichardo Galán and Lucas Platero were also consulted, and the snowball method was used to identify other data sources from those detected during the review. This allowed for the identification of 27 additional documents. All records were checked by the first author, and no automation mechanism was used. A flow chart to illustrate the process of search and selection of studies to be included in the meta-analysis is presented in Figure 1.
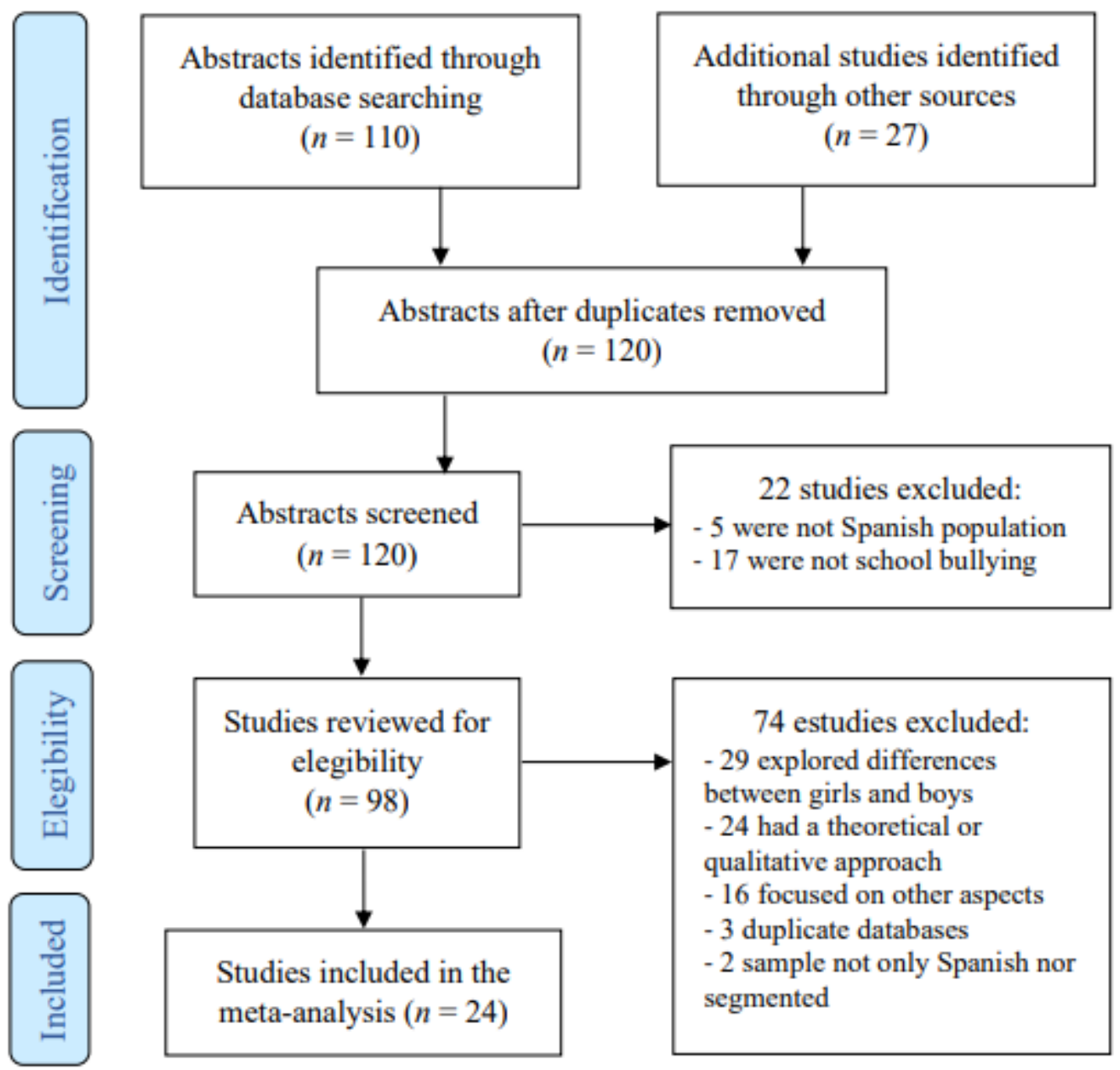

Figure 1. Flowchart of systematic search. Based on PRISMA 2009 Flow Diagram [20].

As for the coding of the information, the following characteristics of the studies were collected: the autonomous community(ies) in which the study was conducted; the size of the sample $(n)$ whose rate is reported; the instrument used to identify bullying; the time frame and frequency needed to consider it to be bullying and not just isolated violent conduct; the rates of gender-based bullying; and finally other data of interest about the study that could facilitate the interpretation of the results. When the documents did not 
explicitly include the rates, but provided sufficient information to calculate them (i.e., the absolute frequency), this calculation was made. On the other hand, when several rates of behaviours that may constitute bullying were provided, but not an overall rate, a conservative choice was made to include only the highest rate (not the aggregate because it could cause an overlap of the sample involved). Table 1 presents a summary of the most relevant information from the studies analysed. In addition, the characteristics of some of the studies analysed seemed to indicate that they shared the same database, so in order not to duplicate the results, only the first published paper was included (therefore, as indicated in the flow chart, three studies were excluded). These studies were Martxueta [23], Orue et al. [24], and Larrain and Garaigordobil [25].

The studies found had not only addressed involvement in bullying as a victim, but some had also investigated the observation of bullying of LGBT+ people or even the perpetration of bullying towards them. Thus, databases differentiated according to the type of involvement reported (victimisation, perpetration, observation) were created using Microsoft Excel 2019. In terms of victimisation, three clearly differentiated target populations were detected: the general population, LGBT+ people concretely, and victims of bullying who reported the reasons behind their victimisation and these reasons were gender-based (specifically, LGBT-phobic). Given the apparent variability of these populations and the prevalence associated with them, it was decided to conduct several meta-analyses based on these different target populations and not only on the type of involvement in bullying. According to the recommendations of Valentine et al. [26], even if a small number of studies are included, it is still relevant to conduct a meta-analysis. Thus, a total of five metaanalyses were conducted with different studies: (1) one with studies reporting observation $(n=5)$; (2) one with studies addressing perpetration $(n=6)$; (3) one with gender-based victimisation reported by the general population $(n=8)$; (4) one with victimisation prevalence among LGBT+ people $(n=9)$; (5) and finally, one with prevalence reported by victims of bullying indicating gender-based reasons behind the victimisation $(n=5)$. The study of Sastre et al. [19] was included in both the meta-analysis with the general population as well as in the victims one, as it provided data on both kinds of samples.

The R programming language [27] was used to synthesise the results and produce descriptive graphs, specifically the "meta" [28] and "metafor" [29] packages. Randomeffects models were used to account for the heterogeneity of the various studies included in each meta-analysis and also to have greater generalisability of the results [30]. Following Viechtbauer's recommendations [29], direct proportions were used as effect sizes when the observed proportions identified in the studies were between 0.20 and 0.80 , as was the case for studies conducted specifically with LGBT+ people. On the other hand, logit transformations were used when proportions smaller than 0.20 were manipulated, such as those found in studies with the general population or with victims of bullying. 
Table 1. Characteristics of the studies selected for inclusion in the meta-analysis.

\begin{tabular}{|c|c|c|c|c|c|c|c|}
\hline STUDY & REGION & SAMPLE & SAMPLE AGE \& SEX & INSTRUMENT & TIME FRAME & FREQUENCY & RATE \\
\hline 1. Gualdi et al., 2008 [31] & Madrid & 152 students & Not reported & Self-reported item & Last academic year & At least once & $73 \%$ victimisation \\
\hline 2. Garchitorena, 2009 [32] & Whole Spain & 325 LGBT+ students & $\bar{x}=20.9 ; 45.5 \%$ girls & Self-reported item & Whole lifetime & At least once & $56.8 \%$ victimisation \\
\hline 3. INJUVE, 2011 [33] & Whole Spain & 1411 participants & Between 15 and $29 ; 49 \%$ girls & Self-reported item & Whole lifetime & At least once & $75 \%$ observation \\
\hline 4. Generelo, 2012 [34] & Whole Spain & $653 \mathrm{LGBT}+$ students & Under $25 ; 34 \%$ girls & Self-reported item & Whole lifetime & At least once & $71 \%$ victimisation \\
\hline 5. López et al., 2013 [16] & Whole Spain & 762 LGBT+ participants & Different ages; $41 \%$ women & Self-reported item & Whole lifetime & At least once & $76 \%$ victimisation \\
\hline 6. Pichardo et al., 2013 [13] & $\begin{array}{l}\text { Madrid and Canary } \\
\text { Islands }\end{array}$ & 4636 students & $\begin{array}{l}\text { Between } 11 \text { and } 19 \\
50.21 \% \text { girls }\end{array}$ & Self-reported item & Whole lifetime & At least once & $\begin{array}{l}16 \% \text { victimisation } \\
30.5 \% \text { perpetration } \\
83.2 \% \text { observation }\end{array}$ \\
\hline 7. FELGTB, 2013 [35] & Whole Spain & 1000 LGBT+ students & Not reported & Self-reported item & Whole lifetime & At least once & $65.3 \%$ victimisation \\
\hline 8. Martxueta \& Etxeberria, 2014 [36] & Basque Country & 119 LGBT+ students & $\begin{array}{l}\text { Different ages; } 26.89 \% \\
\text { women }\end{array}$ & $\begin{array}{l}\text { Olweus Bully/Victim } \\
\text { Questionnaire }\end{array}$ & Last two months & At least once & $30.25 \%$ victimisation \\
\hline $\begin{array}{l}\text { 10. Fundación Mutua Madrileña \& } \\
\text { Fundación ANAR, } 2016 \text { [37] }\end{array}$ & Whole Spain & 550 victims & Not reported & Self-reported item & Whole lifetime & At least once & $2.7 \%$ victimisation \\
\hline 11. Benítez-Deán, 2016 [38] & Community of Madrid & 5605 students & $\begin{array}{l}\text { Secondary students (age not } \\
\text { reported) } 49.07 \% \text { girls }\end{array}$ & Self-reported items & Whole lifetime & At least once & $\begin{array}{l}3.04 \% \text { victimisation } \\
59.68 \% \text { observation }\end{array}$ \\
\hline 12. Sastre et al., 2016 [19] & Whole Spain & 21,487 students & $\begin{array}{c}\text { Between } 12 \text { and } 16 \text { years } \\
48.3 \% \text { girls }\end{array}$ & EBIPQ and ECIPQ & Last two months & At least once per week & $\begin{array}{l}0.3 \% \text { victimisation } \\
0.32 \% \text { perpetration }\end{array}$ \\
\hline $\begin{array}{l}\text { 13. Fundación Mutua Madrileña \& } \\
\text { Fundación ANAR, } 2017 \text { [39] }\end{array}$ & Whole Spain & 365 victims & Not reported & Self-reported item & Whole lifetime & At least once & $2.9 \%$ victimisation \\
\hline 14. Generalitat Valenciana, 2017 [40] & Valencian Community & 2484 victims & Not reported & $\begin{array}{l}\text { Bullying reports } \\
\text { intervened by school } \\
\text { management teams }\end{array}$ & 2015-2016 school year & At least once & $5.39 \%$ victimisation \\
\hline $\begin{array}{l}\text { 15. Gutiérrez-Barroso \& Pérez-Jorge, } \\
2017 \text { [41] }\end{array}$ & Canary Islands & 3723 students & $\begin{array}{l}\text { Secondary students (age not } \\
\text { reported), } 50 \% \text { girls } \\
\text { Not reported for LGBT+ }\end{array}$ & Self-reported item & Last year & At least once & $\begin{array}{l}14.7 \% \text { victimisation } \\
5.9 \% \text { perpetration }\end{array}$ \\
\hline 16. Elipe et al., 2018 [42] & Andalusia & 69 LGBT+ students & $\begin{array}{c}\text { subsample (Overall: } \bar{x}=14.9, \\
49.4 \% \text { girls) }\end{array}$ & EBIPQ & Last two months & At least once per week & $45.4 \%$ victimisation \\
\hline $\begin{array}{l}\text { 17. Fundación Mutua Madrileña \& } \\
\text { Fundación ANAR, } 2018 \text { [43] }\end{array}$ & Whole Spain & 247 victims & Not reported & Self-reported item & Whole lifetime & At least once & $3.2 \%$ victimisation \\
\hline 18. Orue \& Calvete, 2018 [44] & Basque Country & 791 students & $\begin{array}{c}\bar{x}=13.96 \text { years } \\
43.61 \% \text { girls }\end{array}$ & $\begin{array}{l}\text { Escala de acoso escolar } \\
\text { homofóbico }\end{array}$ & Last month & At least once & $\begin{array}{l}79 \% \text { observation } \\
23.2 \% \text { perpetration }\end{array}$ \\
\hline 19. Aparicio-García et al., 2018 [45] & Whole Spain & 233 LGBT+ students & $\begin{array}{l}\text { Not reported for LGBT+ } \\
\text { subsample (Overall between } \\
14 \text { and } 25 \text { years) }\end{array}$ & Self-reported items & Whole lifetime & At least once & $42.9 \%$ victimisation \\
\hline $\begin{array}{l}\text { 20. Kualitate Lantaldea \& ALDARTE, } \\
2018 \text { [46] }\end{array}$ & Basque Country & $107 \mathrm{LGBT}+$ participants & Not reported & Self-reported items & Whole lifetime & At least once & $45 \%$ victimisation \\
\hline 21. Albaladejo-Blázquez et al., 2019 [47] & Valencian Community & 1723 students & $\begin{array}{c}\bar{x}=13.39 \text { years } \\
49 \% \text { girls }\end{array}$ & $\begin{array}{l}\text { The Homophobic Verbal } \\
\text { Content Bullying of HCAT }\end{array}$ & Last week & Three or more times & $\begin{array}{l}25.31 \% \text { victimisation } \\
29.48 \% \text { perpetration }\end{array}$ \\
\hline $\begin{array}{l}\text { 22. Rodríguez-Hidalgo \& } \\
\text { Hurtado-Mellado, } 2019 \text { [48] }\end{array}$ & Andalusia & 820 students & $\begin{array}{c}\bar{x}=14.87 \text { years } \\
51.7 \% \text { girls }\end{array}$ & Homophobic EBIPQ & Last two months & At least once per week & $23 \%$ victimisation \\
\hline 23. Martínez-Gómez et al., 2019 [49] & Valencian Community & 87 students & $\begin{array}{c}\bar{x}=13,34 \text { years } \\
50.6 \% \text { girls }\end{array}$ & $\begin{array}{l}\text { Escala de Vivencias de } \\
\quad \text { discriminación }\end{array}$ & Whole lifetime & At least once & $\begin{array}{l}13 \% \text { victimisation } \\
10.4 \% \text { perpetration } \\
89.5 \% \text { observation }\end{array}$ \\
\hline 24. Garaigordobil \& Larrain, 2020 [50] & Basque Country & 219 LGBT+ students & $\begin{array}{l}\text { Not reported for LGBT+ } \\
\text { subsample (Overall: between } \\
13 \text { and } 17 \text { years, } 52.6 \% \text { girls) }\end{array}$ & $\begin{array}{l}\text { Escala de Screening de acoso } \\
\text { entre iguales }\end{array}$ & Whole lifetime & At least several times & $25.1 \%$ victimisation \\
\hline
\end{tabular}




\section{Results}

Of the studies included in the different meta-analyses, one was carried out with a sample from three different Autonomous Communities (Community of Madrid, Canary Islands and Andalusia); one with a sample from the Community of Madrid and the Canary Islands; two were carried out only in the Community of Madrid; one in the Canary Islands; four in the Basque Country; three in the Community of Valencia; and two in Andalusia. The rest $(n=10)$ were carried out in an attempt to cover samples distributed geographically throughout Spain. All the studies found have been published since 2008, and 15 of them specifically only in the last 5 years. In terms of sample size, 10 of the studies had a sample size of less than 400 , the smallest $n=69$, and the largest $n=21,487$. The most common type of study was a cross-sectional analysis using a survey-type research tool. It was also found that the measurement instrument used was different in almost all cases. Only eight papers used multi-item tools, three studies used the European Bullying Intervention Project Questionnaire [EBIPQ], another used the Olweus Bully/Victim Questionnaire, another used The Homophobic Verbal Content Bullying subscale of the Homophobic Content Agent Target scale [HCAT], another used the Escala de acoso escolar homofóbico (Homophobic Bullying Scale), another the Escala de Vivencias de Discriminación debido a la Orientación o la Identidad Sexual (Experiences of Discrimination due to Sexual Orientation or Sexual Identity Scale), and the Escala de Screening de Acoso entre Iguales (Peer Bullying Screening Scale) was used by the eighth study. There was one study that employed an entirely unique methodology, consisting of assessing the reports of situations of alleged bullying intervened by school management teams. All the other studies used one or more items elaborated by the authors' ad hoc, in which each participant self-reported having experienced, committed, or observed the item described (bullying in general or a specific behaviour). The materials used were not the only thing that differed from one study to another, as the definitions of the timing of having experienced bullying and what was understood by bullying were also not homogeneous from one study to another. However, in order to retain as much information as possible, it was decided to include all identified studies in the appropriate meta-analysis. This variability between studies is reflected in the meta-analyses, all of which have an $\mathrm{I}^{2}$ index (heterogeneity) between $78 \%$ and $100 \%$.

First, a meta-analysis of the results on the observation of gender-based bullying was carried out. This involved an aggregate $n$ of 12,682 participants, spread across six different studies. The total prevalence extracted by the random effects model was $77.3 \%$, with a $95 \%$ confidence interval (CI) of between $65.9 \%$ and $85.7 \%$. Figure 2 shows the dispersion of the data extracted from each of the studies, as well as the information associated with the meta-analysis.

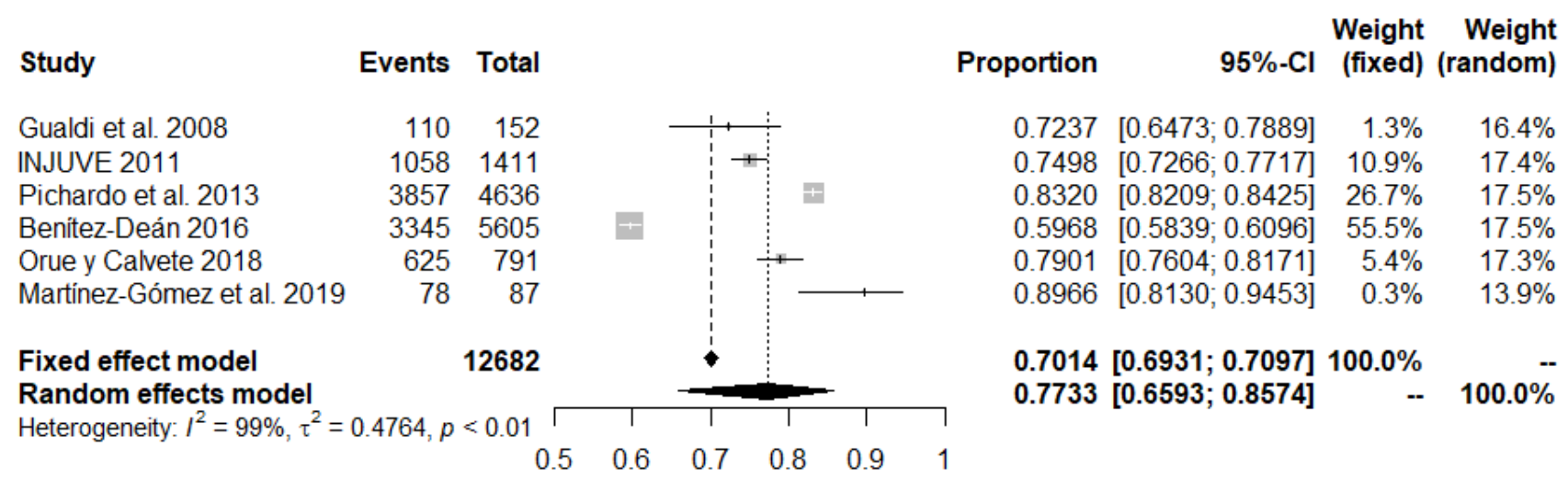

Figure 2. Forest plot of bullying observation studies.

A second meta-analysis was then conducted on the results of gender-based bullying perpetration, with an aggregated sample of 32,447 participants from six different studies. The total prevalence extracted following the random effects model was $13.35 \%$, with a $95 \%$ confidence interval (CI) of between $4.8 \%$ and $31.8 \%$ (see Figure 3 ). 


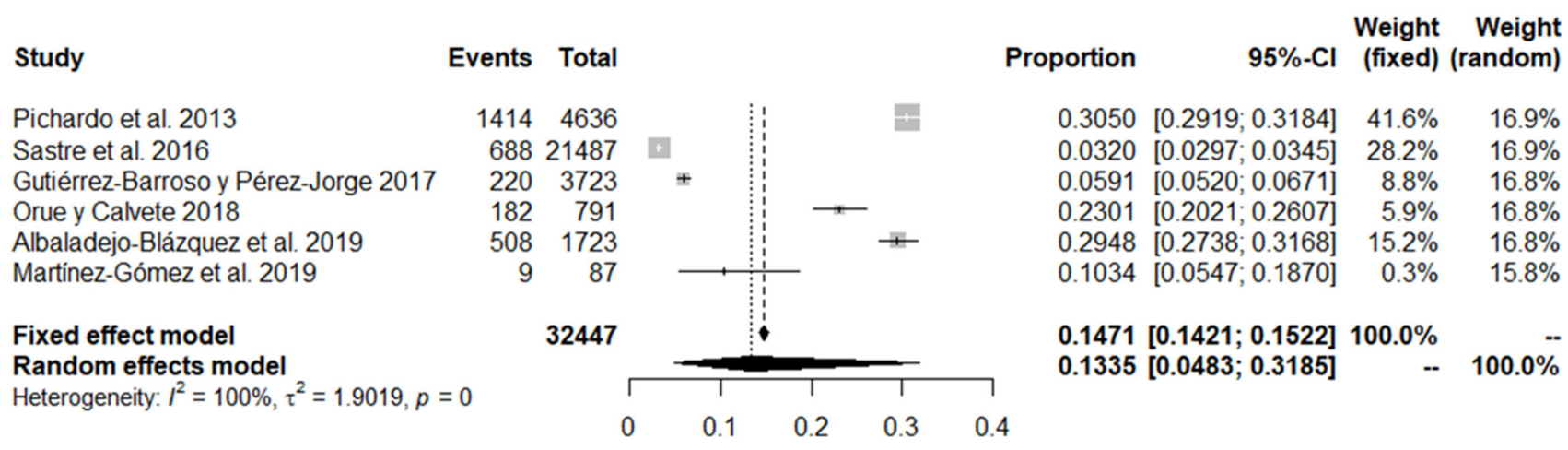

Figure 3. Forest plot of bullying perpetration studies.

On the other hand, for the synthesis of the victimisation results, a meta-analysis was carried out with the results obtained from the general population. This involved an aggregate sample of 41,317 participants from 8 different studies. The total prevalence extracted following the random effects model was $8.6 \%$, with a $95 \%$ confidence interval (CI) of between $4.5 \%$ and $15.9 \%$. Figure 4 shows the dispersion of the data extracted from each of the studies, as well as the information associated with the meta-analysis.

Study

Pichardo et al. 2013

Pichardo et al. 2015

Benitez-Deán 2016

Sastre et al. 2016

Gutiérrez-Barroso y Pérez-Jorge 2017

Albaladejo-Blázquez et al. 2019

Rodríguez-Hidalgo y Hurtado-Mellado 2019

Martinez-Gómez et al. 2019

Fixed effect model

Random effects model

Heterogeneity: $I^{2}=100 \%, \tau^{2}=0.9924, p=0$

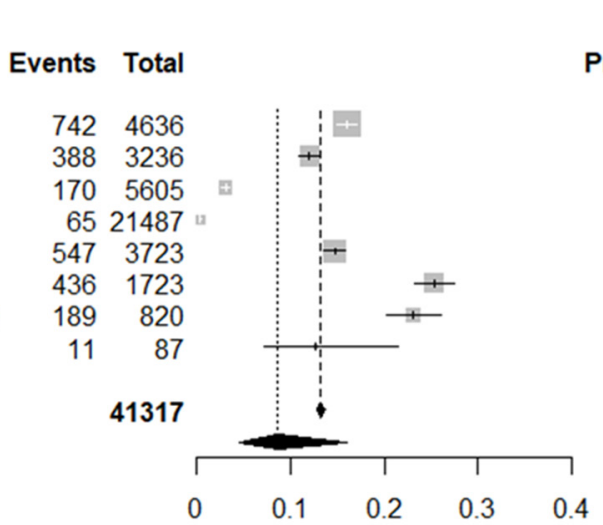

Weight Weight

$95 \%-\mathrm{Cl}$ (fixed) (random)

Figure 4. Forest plot of bullying victimisation among general population studies.

The following meta-analysis was carried out with the results obtained from LGBT+ people, either because of their sexual orientation or gender identity. An aggregate sample of 3487 participants across nine different studies was used. The total prevalence extracted by the random effects model was $51.1 \%$, with a $95 \%$ confidence interval (CI) of between $39.9 \%$ and $62.3 \%$ (see Figure 5 ).

\section{Study}

\section{Garchitorena 2009}

Generelo 2012

López et al. 2013

FELGTB 2013

Martxueta y Etxeberria 2014

Elipe et al. 2018

Aparicio-Garcia et al. 2018

Kualitate Lantaldea y ALDARTE 2018

Garaigordobil y Larrain 2020

Fixed effect model

Random effects model

Heterogeneity: $I^{2}=98 \%, \tau^{2}=0.0284, p<0.01$

\section{Events Total}

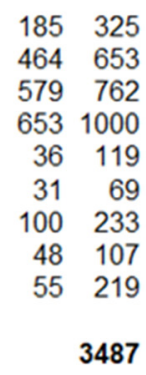

3487

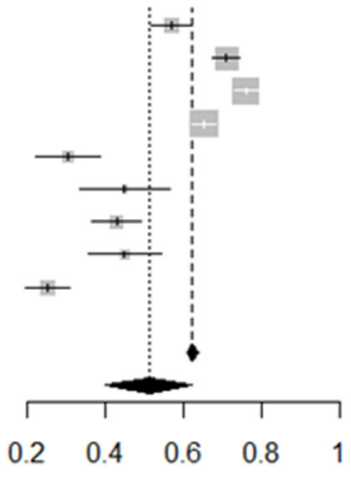

Figure 5. Forest plot of bullying victimisation among LGBT+ people studies. 
Finally, the last meta-analysis conducted included the five studies that addressed the gendered motivations behind the bullying of pre-identified victims. This analysis had an aggregate sample of 5644 participants and revealed an overall prevalence of $3.6 \%$, with a $95 \%$ confidence interval (CI) of between $2.6 \%$ and $5 \%$. This is the analysis with the lowest, but still high, heterogeneity $\left(\mathrm{I}^{2}=78 \%\right)$. Figure 6 details the information from this analysis.

Study
Fundación Mutua Madrileña y Fundación, ANAR 2016
Sastre et al., 2016
Fundación Mutua Madrileña y Fundación ANAR, 2017
Generalitat Valenciana, 2017
Fundación Mutua Madrileña y Fundación ANAR, 2018
Fixed effect model
Random effects model
Heterogeneity: $I^{2}=78 \%, \tau^{2}=0.1057, p<0.01$
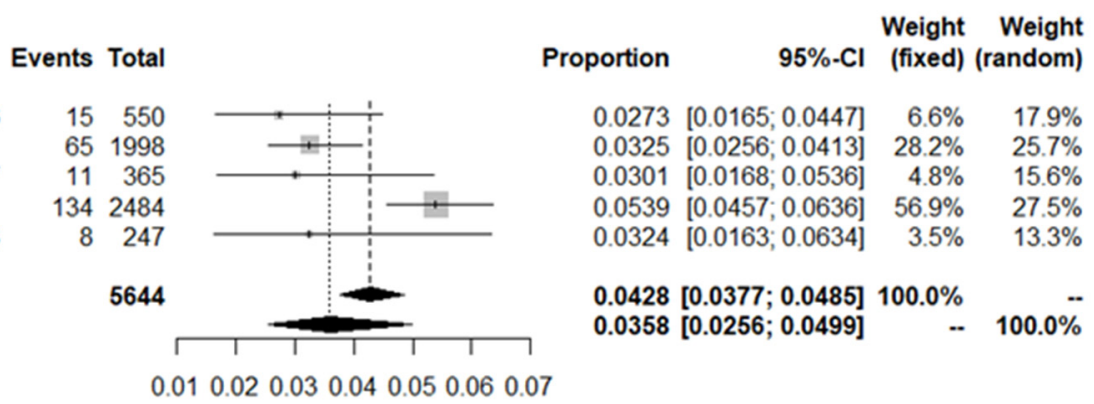

Figure 6. Forest plot of gender-based bullying victimisation among pre-identified victims' studies.

Regarding the detection of publication bias, no formal analysis has been applied in the present study for this purpose, as Egger's regression test is discouraged for meta-analyses of 25 or fewer studies [51].

\section{Discussion}

The present meta-analytical study had been proposed with the main objective of systematically reviewing and meta-analysing the research carried out on the prevalence of gender-based bullying among schoolchildren and adolescents in the Spanish context. In this sense, diverse sources of information with even more diverse realities have been found. Violence not only has consequences on those who suffer it and those who perpetrate it, but also on those who observe it [52], so it was of interest to know the reality of victims and perpetrators, but also that of observers. The results of the present study have established the prevalence of observation of gender-based bullying in Spain at $77.3 \%$, perpetration at $13.35 \%$, and victimisation at $8.6 \%$. However, it should be taken into account that the latter figure covers the entire population, whereas when the research focuses on the previously identified victims of bullying, it is estimated at $3.6 \%$. Furthermore, if studies focus on people with sexual orientations or gender identities other than the "norm", bullying rises up to $51 \%$. Some studies also reported online bullying or cyberbullying, but their samples were very disparate to be included in the same meta-analysis: Generelo [34] reported victimisation among LGBT+ participants, while Fundación Mutua Madrileña and Fundación ANAR [37,39,43] and Sastre et al. [19] reported gender-based bullying among previously identified victims. Regarding the places where bullying seems to occur most frequently, those are the spaces in which students spend more time in contact, such as the classroom during classes, the playground, and particularly the classroom and the corridors of the school during the time between classes [18].

Research on gender-based bullying in Spain is limited to little more than the last dozen years. The first study found addressing this issue was published in 2008 [31]. Until 2013, almost one study per year was published, with a substantial increase from 2016 onwards. There were both specific research as well as studies on bullying in general that addressed the motivations behind the bullying, the groups that suffer it or the potential homophobic content. This homophobic content is present regardless of whether or not the person who had suffered the bullying did actually identify as LGBT+ [48]. This highlights the difficulties in addressing gender-based bullying. On the other hand, it is worth noting the high number of studies $(n=29)$ that were discarded because despite appearing with the identifier "gender", they actually explored "sex" differences between girls and boys. The way in which both constructs are understood by both researchers and study participants may be a major bias in the research. While sex is a biological characteristic associated 
with physical and physiological traits, gender is a social construct related to the roles, behaviours, and identities associated with a particular sex [53]. Sex and gender are often binarily categorised as "female" or "male" and are sometimes used interchangeably due to their complex relationship [54].

If the conceptualisation of gender is already controversial, it is even more controversial to address and define gender-based bullying. The studies included in the meta-analysis addressed homophobic or transphobic bullying, or even simply attacks on non-heterosexual people. Comparing LGBT+ people within the same sample with cis-heterosexual people (i.e., those whose gender identity matches their physiological sex) finds that LGBT+ people experience higher rates of bullying [42,50]; however, it cannot be guaranteed that the motivation behind the bullying is LGBT-phobic. On the other hand, focusing on LGBT+ victims also ignores that there are cis-heterosexual people who suffer homophobic attacks because they do not fit traditional gender roles [5,10]. Some of the reviewed studies have openly addressed homophobic bullying suffered by people regardless of their real orientation or identity [48]. Special mention should be made of the study of DonosoVázquez et al. [55] that was excluded during the Eligibility phase of the search as it was focused on the online setting and not schools. Although it was not included in the metaanalysis, it constituted a true analysis of gender-based violence, exploring a wide range of motivations linked to heterosexism, such as transgressing female sexual normativity or the heteronormative beauty canon.

In addition to the difficulties present in the study of bullying in a specific group, research on bullying, in general, has an inherent series of obstacles when carrying out a comparative and integrative analysis of prevalence due to the diversity of samples, instruments and methodologies used in different investigations [56-58]. In this sense, in the present review, we found immense diversity - from a study focused solely on the verbal content of bullying during the last week [47], and another on LGBT+ people's lifetime bullying assessed retrospectively [36], to a review of the motivations behind bullying cases intervened in schools [40], or a study using a multi-item tool adapted to ask about homophobic bullying during the previous two months [48]. The type of behaviours that are recorded as bullying may have an impact on the reported rates, as when the same research studied different types of bullying suffered, the most frequent attacks were verbal, while physical aggressions were less frequent $[32,33,38]$. These results are similar to those frequently reported in the general literature on bullying [59].

On the other hand, Zych et al. [60] pointed out that the rates of cyberbullying found in local studies vary so substantially that it was advisable not to extrapolate them to the whole country or to other regions. Thus, the lack of specific bullying studies in certain areas of Spain may pose a major problem for the effective prevention of this issue. Specifically, the only Autonomous Communities that had carried out studies addressing the problem of gender-based bullying were the Community of Madrid [13,18,31,38], the Canary Islands $[13,18,41]$, the Basque Country $[36,44,46,50]$, the Valencian Community $[40,47,49]$, and Andalusia [42,48]. Although several of the studies had attempted to access samples from the entire country $[16,19,32-35,45]$, not providing data segmented by CCAA or not guaranteeing the representativeness of the different communities in the total sample, means that the lack of information in certain regions of Spain constitutes a score to settle by the research community.

Regarding the possible limitations of the present study, first of all, the controversial terminology used to describe the object of study should be mentioned, which makes it difficult to correctly identify the research carried out on the subject. At the same time, numerous documents have been detected through their citation in the studies identified in the databases (snowball effect) that did not use any words referring to gender-based bullying as key terms. On the positive side, this may indicate the transversality that this issue is adopting, but it may also imply that this meta-analytical review may have failed to identify relevant documents. In addition, many of the studies that were found came from the autonomous communities themselves or from associations, highlighting 
the need for greater involvement of the scientific community in researching this topic. Besides, future systematic reviews or meta-analyses could benefit from the inclusion of more databases (Web of Science, PsychINFO, etc.). Finally, although the great disparity at the conceptual level of the studies to be synthesised is a problem common to all research on bullying [56,57], the use of different time criteria, instruments, and methodologies means that the studies included in the same meta-analysis present great heterogeneity. In an attempt to minimise this limitation, the reported data have been calculated using a random effects model. This high heterogeneity reveals the need to detect which variables may be moderating the disparity in reported rates from one study to another. Future work should explore these moderating factors using meta-regression techniques if the number of available studies allows it. On the other hand, as it has already been highlighted by another meta-analytic review outside the Spanish context [58], it would be very useful for studies on bullying to provide sufficient information to estimate prevalence, since not all the studies identified at the outset were likely to be included in a meta-analysis. Furthermore, the research community is encouraged to further explore the motivations and causes behind bullying, rather than just reporting overall rates. Finally, there is also the need to conduct further research to analyse how the situation may have changed due to the COVID-19 pandemic, as the study of Vaillancourt et al. in Canada seemed to indicate that, while the pandemic may have mitigated bullying rates in general, the victimisation of gender-diverse and LGBT+ students remained higher than their gender binary or heterosexual peers [7].

\section{Conclusions}

The meta-analyses conducted with $\mathrm{R}$ have estimated the prevalence of observation of gender-based school bullying in Spain at $77.3 \%$, perpetration at $13.3 \%$, and victimisation at $8.6 \%$ among the general population. When the research focuses on previously identified victims that report gender-based reasons behind the bullying, the rate was $3.6 \%$, while if LGBT+ people are asked directly about their bullying experiences, the percentage increases to $51 \%$. The results of this meta-analytic review should have important implications for the study and intervention of gender-based bullying in Spain. The violation of human rights it represents and the impact it poses to both the social and individual well-being for one out of every two LGBT+ people suffering it should motivate the development of specific preventive strategies. It may be argued that greater awareness of affective-sexual diversity and respect for those who do not conform to traditional gender roles should be promoted in education, and society as a whole.

Author Contributions: Conceptualisation, S.F. and R.R.-F.; methodology, S.F. and R.R.-F.; software, S.F.; formal analysis, S.F.; investigation, S.F. and R.R.-F.; writing-original draft preparation, S.F.; writing-review and editing, R.R.-F.; supervision, S.F. and R.R.-F. All authors have read and agreed to the published version of the manuscript.

Funding: This research received no external funding.

Institutional Review Board Statement: Not applicable.

Informed Consent Statement: Not applicable.

Acknowledgments: The authors want to thank Lita Feijóo for proofreading the English writing. No sources of funding were used in the preparation of this article.

Conflicts of Interest: The authors declare no conflict of interest.

\section{References}

1. Olweus, D. Bullying at School: What We Know and What We Can Do; Blackwell Publishers: Oxford, UK, 1993.

2. O'Higgins Norman, J. Homophobic Bullying in Irish Secondary Education; Academica Press: Washington, DC, USA, 2008.

3. O'Moore, M. Understanding School Bullying. A Guide for Parents and Teachers; Veritas: Dublin, Ireland, 2010.

4. Pinquart, M. Systematic Review: Bullying Involvement of Children with and without Chronic Physical Illness and/or Physical/Sensory Disability-A Meta-Analytic Comparison with Healthy/Nondisabled Peers. J. Pediatr. Psychol. 2017, 42, 245-259. [CrossRef] 
5. Platero, L.; Gómez, E. Herramientas para Combatir el Bullying Homofóbico; Talasa: Madrid, Spain, 2007.

6. Centers for Disease Control and Prevention. Youth Risk Behavior Surveillance-United States, 2017; Center for Surveillance, Epidemiology, and Laboratory Services, Centers for Disease Control and Prevention [CDC], U.S. Department of Health and Human Services; 2018. Available online: https:/ / www.cdc.gov/mmwr/volumes /67/ss/pdfs /ss6708a1-h.pdf (accessed on 27 April 2020).

7. Vaillancourt, T.; Brittain, H.; Krygsman, A.; Farrell, A.H.; Landon, S.; Pepler, D. School bullying before and during COVID-19: Results from a population-based randomized design. Aggress. Behav. 2021, 47, 557-569. [CrossRef]

8. Platero, L. La homofobia como elemento clave del acoso escolar homofóbico. Algunas voces desde Rivas Vaciamadrid. Inf. Psicol. 2008, 94, 71-83. Available online: http:/ /www.informaciopsicologica.info/previous_issues.php (accessed on 22 April 2020).

9. Ruiz, A.; Evangelista, A.; Xolocotzi, A. ¿Cómo llamarle a lo que tiene muchos nombres? ¿Bullying, violencia de género, homofobia o discriminación contra personas LGBTI? Rev. Interdiscip. Estud. Género Col. México 2018, 4, e210. [CrossRef]

10. Amnesty International. Hacer la Vista ... ;Gorda! El Acoso Escolar en España, un Asunto de Derechos Humanos; Amnistía Internacional España: Madrid, Spain, 2019; Available online: https:/ / www.observatoriodelainfancia.es/ficherosoia/documentos/5836_d_ Informe-Amnistia_Acoso-Escolar-2019.pdf (accessed on 22 April 2020).

11. Blaya, C.; Debarbieux, E.; Lucas Molina, B. La violencia hacia las mujeres y hacia otras personas percibidas como distintas a la norma dominante: El caso de los centros educativos. Rev. Educ. 2007, 342, 61-81. Available online: http://www.educacionyfp. gob.es/revista-de-educacion/inicio.html (accessed on 28 April 2020).

12. Ley Orgánica $1 / 2004$, de 28 de Diciembre, de Medidas de Protección Integral Contra la Violencia de Género. Boletín Off. Estado 2004, 313. Available online: https:/ / www.boe.es/buscar/act.php?id=BOE-A-2004-21760 (accessed on 28 April 2020).

13. Molinuevo Puras, B.; Rodríguez Medina, P.O.; Romero López, M. Actitudes Ante la Diversidad Sexual de la Población Adolescente de Coslada (Madrid) y San Bartolomé de Tirajana (Gran Canaria); FELGTB: Madrid, Spain, 2013.

14. Generelo Lanaspa, J.; Pichardo Galán, J.I. Homofobia en el Sistema Educativo; Comisión de Educación de COGAM: Madrid, Spain, 2006; Available online: http:/ / www.felgtb.org/rs/466/d112d6ad-54ec-438b-93584483f9e98868/807/filename/homofobia-enel-sistema-educativo.pdf (accessed on 27 April 2020).

15. Rainbow Europe. Available online: https:// rainbow-europe.org/country-ranking (accessed on 8 October 2021).

16. López, A.; Generelo, J.; Arroyo, A. Estudio 2013 Sobre Discriminación por Orientación Sexual y/o Identidad de Género en España; FELTGTB: Madrid, Spain, 2013; Available online: http:/ /www.felgtb.org/rs/2447/d112d6ad-54ec-438b-9358-4483f9e98868/bd2 / filename/estudio-2013-sobre-discriminacion-por-orientacion-sexual-y-o-identidad-de-genero-en-espana.pdf (accessed on 18 August 2020).

17. Maroto, A.L. Homosexualidad y Trabajo Social. Herramientas para la Reflexión e Intervención Profesional; Siglo XXI Editores España: Madrid, Spain, 2006.

18. Pichardo Galán, J.I.; de Stéfano Barbero, M.; Sánchez Sainz, M.; Puche Cabezas, L.; Molinuevo Puras, B.; Moreno Cabrera, O. Diversidad Sexual y Convivencia: Una Oportunidad Educativa; Universidad Complutense de Madrid \& FELGTB: Madrid, Spain, 2015.

19. Sastre, A.; Calmaestra, J.; Escorial, A.; García, P.; Del Moral, C.; Perazzo, C.; Ubrich, T. Yo a Eso no Juego. Bullying y Ciberbullying en la Infancia; Save the Children España: Madrid, Spain, 2016; Available online: https://www.savethechildren.es/sites/default/ files/imce/docs/yo_a_eso_no_juego.pdf (accessed on 12 May 2020).

20. Moher, D.; Liberati, A.; Tetzlaff, J.; Altman, D.G.; PRISMA Group. Preferred reporting items for systematic reviews and meta-analysis: The PRISMA statement. PLoS Med. 2009, 6, e1000097. [CrossRef]

21. Botella, J.; Gambara, H. Qué es el Meta-Análisis; Biblioteca Nueva: Barcelona, Spain, 2002.

22. Botella, J.; Sánchez-Meca, J. Meta-Análisis en Ciencias Sociales y de la Salud; Editorial Síntesis: Madrid, Spain, 2015.

23. Martxueta, A. Consecuencias del bullying homofóbico retrospectivo y los factores psicosociales en el bienestar psicológico de sujetos LGB. Rev. Investig. Educ. 2014, 32, 255-271. [CrossRef]

24. Orue, I.; Calvete, E.; Fernández-González, L. Adaptación de la “Escala de acoso escolar homofóbico” y magnitud del problema en adolescentes españoles. Psicol. Conduct. 2018, 26, 437-455. [CrossRef]

25. Larrain, E.; Garaigordobil, M. El Bullying en el País Vasco: Prevalencia y Diferencias en Función del Sexo y la Orientación-Sexual. Clin. Salud 2020, 31, 147-153. [CrossRef]

26. Valentine, J.C.; Pigott, T.D.; Rothstein, H.R. How Many Studies Do You Need? A Primer on Statistical Power for Meta-Analysis. J. Educ. Behav. Stat. 2010, 35, 215-247. [CrossRef]

27. R Core Team. R: A Language and Environment for Statistical Computing; R Foundation for Statistical Computing: Vienna, Austria, 2019.

28. Balduzzi, S.; Rücker, G.; Schwarzer, G. How to perform a meta-analysis with R: A practical tutorial. Evid. Based Ment. Health 2019, 22, 153-160. [CrossRef] [PubMed]

29. Viechtbauer, W. Conducting Meta-Analyses in R with the metaphor Package. J. Stat. Softw. 2010, 36, 1-48. [CrossRef]

30. Vevea, J.L.; Coburn, K.M. Maximum-likelihood methods for meta-analysis: A tutorial using R. Group Process Intergroup Relat. 2015, 18, 329-347. [CrossRef]

31. Gualdi, M.; Martelli, M.; Wilhelm, W.; Biedrón, R.; Graglia, M.; Pietrantoni, L. Schoolmates. Bullying Homofóbico en las Escuelas. Guía para Profesores; Programa Daphne II: Madrid, Spain, 2008; Available online: www.educatolerancia.com (accessed on 28 August 2020). 
32. Garchitorena, M. Informe Jóvenes LGTB; Ministerio de Trabajo y Asuntos Sociales \& FELGTB: Madrid, Spain, 2009. Available online: http:/ / felgtb.com/stopacosoescolar/wp-content/uploads/2017/08/Informe-jovenes-lgtbred.pdf (accessed on 27 August 2020).

33. Instituto de la Juventud [INJUVE]. Jóvenes y Diversidad Sexual; INJUVE: Madrid, Spain, 2011; Available online: http://www. injuve.es/observatorio/salud-y-sexualidad/jovenes-y-diversidad-sexual (accessed on 17 August 2020).

34. Generelo, J. Acoso Escolar Homofóbico y Riesgo de Suicidio en Adolescentes y Jóvenes LGB; FELGTB \& COGAM: Madrid, Spain, 2012; Available online: https://www.observatoriodelainfancia.es/oia/esp/documentos_ficha.aspx?id=3645 (accessed on 1 September 2020).

35. Federación Estatal de Lesbianas, Gais, Trans y Bisexuales [FELGTB]. Acoso Escolar (y Riesgo de Suicidio) por Orientación Sexual e Identidad de Género: Fracaso del Sistema Educativo; FELGTB: Madrid, Spain, 2013; Available online: https://www. observatoriodelainfancia.es/oia/esp/documentos_ficha.aspx?id=3999 (accessed on 27 August 2020).

36. Martxueta, A.; Etxeberria, J. Análisis diferencial retrospectivo de las variables de salud mental en lesbianas, gais y bisexuales (lgb) víctimas de bullying homofóbico en la escuela. Rev. Psicopatología Psicol. Clínica 2014, 19, 23-35. [CrossRef]

37. Fundación Mutua Madrileña \& Fundación Ayuda a Niños y Adolescentes en Riesgo [ANAR]. I Estudio Sobre Sobre Acoso Escolar y Cyberbullying Según los Afectados; Fundación Mutua Madrileña \& Fundación ANAR: Madrid, Spain, 2016; Available online: https:/ /www.anar.org/wp-content/uploads/2017/03/INFORME-I-ESTUDIO-BULLYING.pdf (accessed on 19 August 2020).

38. Benítez-Deán, E. LGBT-Fobia en las Aulas 2015. ¿Educamos en la Diversidad Afectivo-Sexual? Grupo de Educación del Colectivo de Lesbianas, Gays, Transexuales y Bisexuales de Madrid [COGAM]: Madrid, Spain, 2016; Available online: https://www. bienestaryproteccioninfantil.es $/$ fuentes1.asp?sec=32\&subs=319\&cod=2706\&page (accessed on 27 August 2020).

39. Fundación Mutua Madrileña y Fundación ANAR. II Estudio Sobre Acoso Escolar y Cyberbullying Según los Afectados. Informe del Teléfono ANAR; Fundación Mutua Madrileña \& Fundación ANAR: Madrid, Spain, 2017; Available online: https://www.anar.org/ wp-content/uploads/2017/04/INFORME-II-ESTUDIO-CIBERBULLYING.pdf (accessed on 19 August 2020).

40. Generalitat Valenciana. Memòria Anual_Convivència Escolar en la Comunitat Valenciana. Curs 2015-2016; Generalitat Valenciana: Valencian, Spain, 2017. Available online: http://www.ceice.gva.es/es/web/convivencia-educacion/inicio/_/asset_publisher/ fQo9KePNfRG4/content/publicada-la-memoria-anual-sobre-la-convivencia-escolar-en-la-comunitat-valenciana (accessed on 3 September 2020).

41. Gutiérrez-Barroso, J.; Pérez-Jorge, D. Análisis del Acoso Escolar en Gran Canaria (AAEGC): Prevalencia en Educación Primaria y Secundaria 2017; Cabildo de Gran Canaria. Consejería de Recursos Humanos, Organización, Educación y Juventud: Canary Island, Spain, 2017; Available online: http: / / www.grancanariajoven.es/contenido/Analisis-de-la-prevalencia-del-acoso-escolaren-Gran-Canaria-AAEGC-Prevalencia-en-educacion-primaria-y-secundaria-2017/2090 (accessed on 1 September 2020).

42. Elipe, P.; Muñoz, M.; Del Rey, R. Homophobic Bullying and Cyberbullying: Study of a Silenced Problem. J. Homosex. 2018, 65, 672-686. [CrossRef]

43. Fundación Mutua Madrileña \& Fundación ANAR. III Estudio Sobre Acoso Escolar y Cyberbullying Según los Afectados. Informe del Teléfono ANAR; Fundación Mutua Madrileña \& Fundación ANAR: Madrid, Spain, 2018; Available online: https://www.anar.org/ wp-content/uploads/2018/09/III-Estudio-sobre-acoso-escolar-y-ciberbullying-seg\%C3\%BAn-los-afectados.pdf (accessed on 19 August 2020).

44. Orue, I.; Calvete, E. Homophobic Bullying in Schools: The Role of Homophobic Attitudes and Exposure to Homophobic Aggression. School Psych. Rev. 2018, 47, 95-105. [CrossRef]

45. Aparicio-García, M.E.; Díaz-Ramiro, E.M.; Rubio-Valdehita, S.; López-Núñez, M.I.; García-Nieto, I. Health and Well-Being of Cisgender, Transgender and Non-Binary Young People. Int. J. Environ. Res. Public Health 2018, 15, 2133. [CrossRef] [PubMed]

46. Kualitate Lantaldea \& ALDARTE-Centro de Atención a Gais, Lesbianas y Personas Trans. Diagnóstico Sobre las Realidades de la Población LGTBI en Vitoria-Gasteiz; Servicio de Igualdad, Departamento de Alcaldía y Relaciones Institucionales, Ayuntamiento de Vitoria-Gasteiz: Vitoria-Gasteiz, Spain, 2018. Available online: http:/ /salutsexual.sidastudi.org/es/registro/a53b7fb3673c3a9f0 16876150ec403c1 (accessed on 1 September 2020).

47. Albaladejo-Blázquez, N.; Ferrer-Cascales, R.; Ruiz-Robledillo, N.; Sánchez-SanSegundo, M.; Fernández-Alcántara, M.; Delvecchio, E.; Arango-Lasprilla, J.C. Health-Related Quality of Life and Mental Health of Adolescents Involved in School Bullying and Homophobic Verbal Content Bullying. Int. J. Environ. Res. Public Health 2019, 16, 2622. [CrossRef]

48. Rodríguez-Hidalgo, A.J.; Hurtado-Mellado, A. Prevalence and psychosocial predictors of homophobic victimization among adolescents. Int. J. Environ. Res. Public Health 2019, 16, 1243. [CrossRef] [PubMed]

49. Martínez-Gómez, N.; Giménez-García, C.; Enrique-Nebot, J.; Elipe-Miravet, M.; Ballester-Arnal, R. Discriminación LGBTI en las Aulas. Int. J. Sch. Educ. Psychol. 2019, 1, 367-376. [CrossRef]

50. Garaigordobil, M.; Larrain, E. Acoso y ciberacoso en adolescentes LGTB: Prevalencia y efectos en la salud mental. Comunicar 2020, 62, 79-90. [CrossRef]

51. Rothstein, H.; Sutton, A.J.; Borenstein, M. Publication Bias in Meta-Analysis: Prevention, Assessments and Adjustments; Wiley: Hoboken, NJ, USA, 2006.

52. Garaigordobil, M.; Martínez-Valderrey, V.; Aliri, J. Victimización, percepción de la violencia y conducta social. Infanc. Aprendiz. 2014, 37, 90-116. [CrossRef]

53. Coen, S.; Banister, E. (Eds.) What a Difference Sex and Gender Make: A Gender, Sex and Health Research Casebook; Canadian Institutes of Health Research: Ottawa, ON, Canada, 2021; Available online: https:/ / papers.ssrn.com/sol3/papers.cfm?abstract_id=2199670 (accessed on 1 July 2020). 
54. Heidari, S.; Babor, T.F.; De Castro, P.; Tort, S.; Curno, M. Sex and Gender Equity in Research: Rationale for the SAGER guidelines and recommended use. Res. Integr. Peer Rev. 2016, 1, 2. [CrossRef] [PubMed]

55. Donoso-Vázquez, T.; Rubio, M.J.; Vilà, R. Las ciberagresiones en función del género [Gendered cyber-aggressions]. Rev. Investig. Educ. 2017, 35, 197-214. [CrossRef]

56. Del Barco, B.L.; Castaño, E.F.; Bullón, F.F.; Carroza, T.G. Cyberbullying en una muestra de estudiantes de educación secundaria: Variables moduladoras y redes sociales. Rev. Electron. Investig. Psicoeduc. Psigopedag. 2012, 10, 771-788. [CrossRef]

57. Olweus, D.; Limber, S.P. Some problems with cyberbullying research. Curr. Opin. Psychol. 2018, 19, 139-143. [CrossRef] [PubMed]

58. Vega-Cauich, J.I. Prevalencia del bullying en Mexico: Un meta-análisis del bullying tradicional y cyberbullying. Divers. Perspect. Psicol. 2019, 15, 111-127. [CrossRef]

59. Kennedy, R.S. A meta-analysis of the outcomes of bullying prevention programs on subtypes of traditional bullying victimization: Verbal, relational, and physical. Aggress. Violent Behav. 2020, 55, 101485. [CrossRef]

60. Zych, I.; Ortega-Ruiz, R.; Marín-López, I. Cyberbullying: A systematic review of research, its prevalence and assessment issues in Spanish studies. Psicol. Educ. 2016, 22, 5-18. [CrossRef] 